MINERALOGIA, 44, No 1-2: 13-30 (2013)

DOI: 10.2478/mipo-2013-0002

www.Mineralogia.pl

MineRALOGICAL SOCIETY of Poland

POLSKIE TOWARZYSTWO MINERALOGICZNE

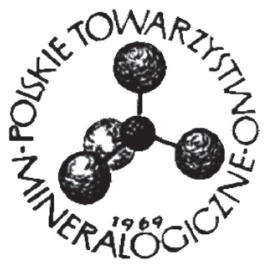

Original paper

\title{
Petrological implications of the Early Mesozoic lamprophyre dikes and related Tarkhata syenites (SE Altai and NW Mongolia)
}

\author{
Elena A. VASYUKOVA ${ }^{1 *}$, Alexander S. BORISENKO ${ }^{1}$ \\ ${ }^{1}$ Institute of Geology and Mineralogy SB RAS, 3 Ak. Koptyuga Av., 630090 Novosibirsk, Russia \\ ${ }^{2}$ Novosibirsk State University, 2 Pirogova St, 630090 Novosibirsk, Russia \\ e-mail:lenav@inbox.ru \\ ${ }^{*}$ Corresponding author
}

Received: January 25, 2011

Received in revised form: December 10, 2013

Accepted: February 2, 2014

Available online: March 28, 2014

\begin{abstract}
This paper presents new data derived from field sampling and from a thorough description of lamprophyres located in southeastern Altai and northwestern Mongolia in terms of their mineralogy, textures, and chemical composition. The swarms of alkaline mafic dikes in the area coexist with granosyenite-monzodiorite and gabbro-dolerite intrusions and spatially coincide with an ore district of $\mathrm{Sb}-\mathrm{Hg}, \mathrm{Ag}-\mathrm{Sb}$, Ni-Co-As, Cu-Mo-W, and $\mathrm{CaF} 2$ hydrothermal mineralization. All lamprophyres belong to the Early Mesozoic Chuya complex formed in an intracontinental enviroment. Their distribution and orientation is controlled by two large fault zones. The Chuya dikes were investigated at two localities, namely, Yustyd and South-Chuya. The Yustyd lamprophyres intrude Middle-Upper Devonian black shale of the Yustyd depression. At South Chuya, lamprophyres, together with the Tarkhata granosyenite-monzodiorite complex, are hosted by Cambrian and Ordovician metamorphic rocks of the South-Chuya Range. Ar-Ar (phlogopite) and U-Pb (SHRIMP, zircon) ages of the lamprophyre dikes indicate long and continuous period of the formation of the Chuya complex (250-235 Ma). Major- and trace-element compositions of the lamprophyres from both localities and of the syenite indicate their origin from the same magma source. The textures and structures of the lamprophyre and plutonic rocks, their mineral assemblages and the chemistry of the rock-forming minerals provide clues to the evolution of the parental alkaline mafic magma and fluid regime.
\end{abstract}

Key-words: lamprophyre, syenites, petrology, SE Altai, NW Mongolia 


\section{Introduction}

The genesis of lamprophyres and its links with mineralization is a very important problem in economic geology. In the southeastern part of Altai the lamprophyre dikes were found during prospecting for the $\mathrm{Hg}$ deposites. Their overlap in time and place with $\mathrm{Hg}$ and other mineralization gave rise to suppose their genetic link. The first description of the lamprophyres in southeastern Altai was by Obolenskaya (1971), who interpreted them to belong to a single Mesozoic Chuya complex on the basis of mineral compositions and K-Ar ages. Found by subsequent workers similar lamprophyres in the nearby region expands the borders of the Chuya complex. However, the dikes have different composition, textures and structures while their classification, origin and relationships with neighboring plutonic rocks and with mineralization remain poorly understood.

The dikes were controlled by the large Terekta-Tolbonur and Kurai-Kobdo long-lived faults; they are located in and near these faults and subsidiary along these structures and subsidiary faults. The dikes are distributed unevenly within the complex and form small fields. Two fields, South-Chuya and Yustyd, were sampled for detailed investigation. The dikes of the first locality, within the South-Chuya Range, occur in grey-green CambrianOrdovician metamorphosed rocks. The Yustyd lamprophyres are emplaced in a thick $(\sim 4 \mathrm{~km})$ Devonian terrigenous sequence of black shales deposited a back-arc basin (Fig. 1).

The dikes of the Chuya complex intrude rocks ranging in age from Middle Cambrian to Middle Devonian. Based on radiometric data (Ar-Ar - phlogopite, U-Pb-SHRIMP - zircon) (Borisenko et al. 2010), there was long continuous period of the lamprophyre intrusion, divided into two stages (236-234 and 250-242 Ma) by ore and granite formation. The alkaline mafic complex is roughly coeval with large-scale mafic magmatism in northern Eurasia associated with the Siberian superplume (Borisenko et al. 2010).

The Chuya lamprophyre dikes are proximal in space and time with the Permian-Triassic Terekta complex of gabbro and dolerite and with the Triassic Tarkhata granosyenitemonzodiorite complex. The latter occurs within the dike field but no contact relationships with the dikes were seen.

We studied the Chuya lamprophyre dikes and the Tarkhata plutonic rocks in terms of their mineralogy, textures and structure features, and their major- and trace-element compositions. The aims were to substantiate the existence of two separate fields within the dike complex, to trace any genetic relationships between the lamprophyres and the coeval granosyenite-monzodiorite rocks, and to constrain the origin of alkaline mafic melts.

\section{Sampling and methods}

Lamprophyre occurrences were described and sampled within the Russian part of the province, over an area from the Aktash $\mathrm{Hg}$ deposit in the north to the Asgat Ag-Sb deposit in the south (Fig. 1). About 120 rock samples were collected from 17 sites. Thin sections (about 150 in total) were prepared from all samples. The thin-section petrography guided the selection of representative samples for mineralogical and chemical analyses.

The chemical compositions of minerals are determined using CAMEBAX-MICRO and JEOL-8100 electron microprobes. Thirty-nine samples of lamprophyre and syenite were selected for whole-rock chemical analyses. The whole-rock major- and trace-element 
chemistry was determined using X-Ray-Fluorescence (XRF) and Mass Spectrometry with Inductively Coupled Plasma (ICP-MS), respectively. The analytical precision was better than 5\% in XRF and 5-10\% for ICP-MS, depending on element abundances (about 5\% for those above $10 \mathrm{ppm}$ and $10 \%$ for those below $10 \mathrm{ppm}$ ). All samples were analyzed at the Sobolev Institute of Geology and Mineralogy, Siberian Branch of Russian Academy of Sciences (Novosibirsk).

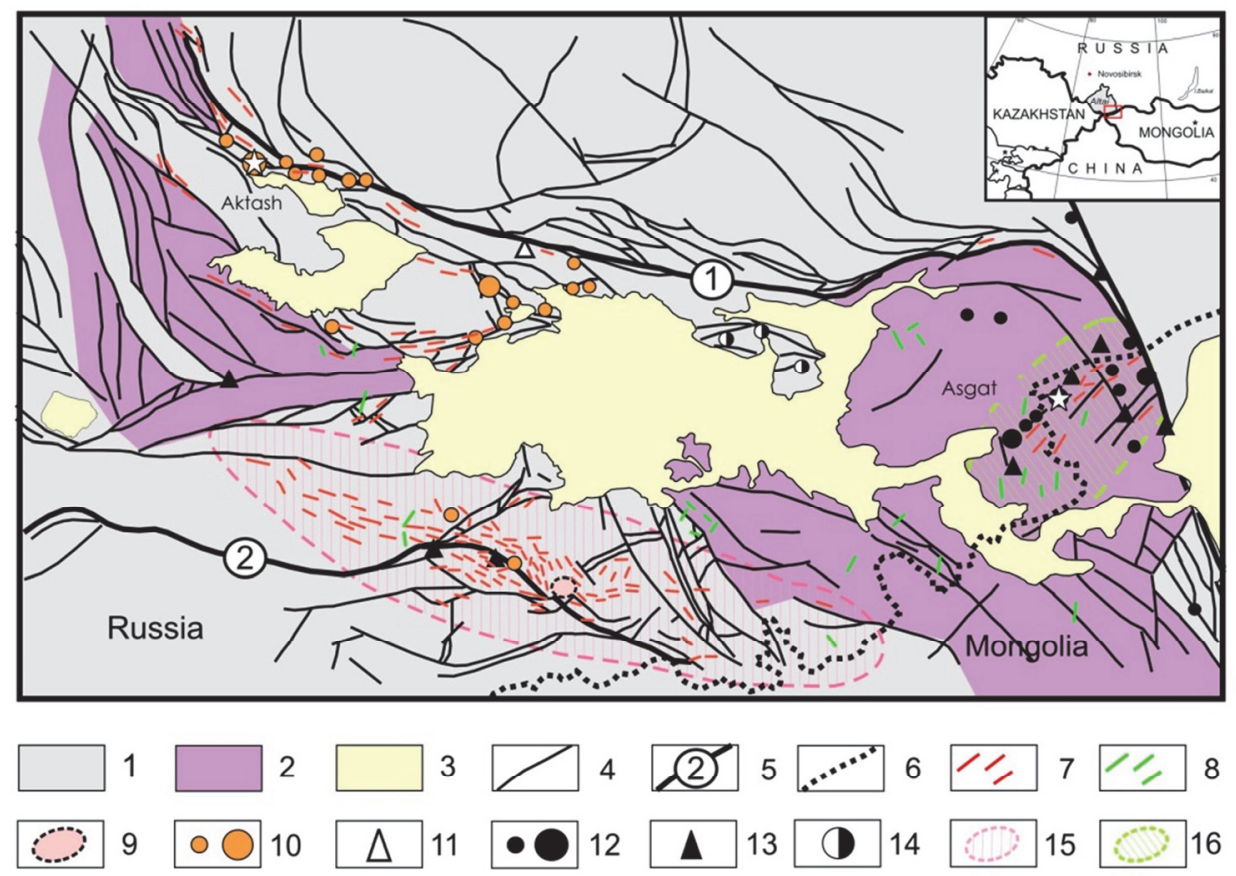

Fig. 1. Schematic map of major occurrences of Early Mesozoic magmatism and mineralization in southeastern Altai and northwestern Mongolia. 1 - Cambrian-Ordovician deposits; 2 - Devonian deposits; 3 - Cenozoic deposits; 4 - faults; 5- fault zones (1 - Kurai-Kobdo, 2 - Terekta-Tolbonur); 6 - Russia-Mongolia frontier; 7 - lamprophyre dikes of the Chuya complex; 8 - gabbro-dolerite Terekhta complex; 9 - Tarkhata granosyenite-monzodiorite complex; 10-14 - mineralization: $10-\mathrm{Hg}, 11$ - fluorite, 12 - Ag-Sb, 13 - Ni-Co-As, 14 - Cu-Hg; 15 - South-Chuya lamprophyre area, 16 - Yustyd lamprophyre area.

\section{Geological setting}

\subsection{South-Chuya and Yustyd lamprophyres}

The dikes are steeply dipping, plate-shaped bodies up $1 \mathrm{~km}$ long and several $\mathrm{cm}$ to $10 \mathrm{~m}$ thick that strike NW-SE or W-E. Obolenskaya (1971) described some small pipe-like bulges composed of crust xenoliths cemented with lamprophyre and volcanic pipes.

The Yustyd lamprophyres, mostly striking W-E, were emplaced along the large KuraiKobdo fault, which originated during Early-Middle Devonian rifting, and along its 
subsidiary faults. The country rocks are thinly interbedded highly carbonaceous aleurolites and shale. The Yustyd dikes consist of coarse or fine-grained minette or, less commonly, kersantite. They typically have a simple structure, with crystallization increasing progressively from the margins to the center and acquiring fine to medium porphyritic textures in the thickest dikes. The margins are chilled and marked by dense coatings of margin-parallel biotite laths.

The South Chuya lamprophyres occur in a Cambrian-Ordovician sequence of sandstone, siltstone, and shale interlayered with limestone lenses. The position and orientation of the dikes are controlled by the large NW-SE Terekta-Tolbonur fault zone. The lamprophyres are minette or leucocratic minette. All dikes have prominent chilled margins delineated by abundant phlogopite laths. There are many complex dikes (dike-in-dike) that record multiple batches of melt emplaced into fractures. Rocks formed by subsequent emplacement of lamprophyre melt into earlier dikes differ either in color (more leucocratic) or in texture. The boundaries between the varieties corresponding to different magma batches are always symmetrical relative to the dike center.

\subsection{The Tarkhata massif}

The Tarkhata massif is the largest one of a complex with the same name that is associated with the South-Chuya lamprophyres. The massif, slightly elongated in a NW direction, intrudes sand-shale sediments and causes quartz-biotite-cordierite hornfels metamorphism. The pluton's northeastern boundary is delineated by a fault and, judging by the geometry of the $400 \mathrm{~m}$ wide zone of contact metamorphism, its southeastern boundary is smooth and gently dipping. Although poorly exposed, the pluton displays evident asymmetric zoning with fine porphyric biotite ( \pm amphibole, \pm pyroxene) monzodiorite and syenite margins (except for the southwestern part) and fine to medium weakly-porphyritic biotite granosyenite and monzogranite in the interior. Smooth transitions between the varieties in the pluton indicate a single-phase structure, while the zoning records fractional crystallization.

\section{Petrography and mineralogy}

\subsection{Texture and structure}

Lamprophyres of the Chuya complex generally look inhomogeneous. However, the inhomogeneity is due rather to different structures and textures than to variations in mineralogy. They may be equigranular and massive or molted and inequigranular or spherulitic, with different textures coexisting within a single thin $(0.5 \mathrm{~m})$ dike. The rocks of the Chuya complex often show directional structures, with biotite flakes aligned with the dike margins (Fig. 2a). The lamprophyres often have spherulitic textures which were assumed at one time, to be a diagnostic feature of mica-bearing varieties. Only the South Chuya dikes have these spherulitic textures which are especially prominent on weathered rock surfaces (Fig. 2b). Their margins are characterized by leucocratic red minette, which may be massive or spherulitic with abundant closely spaced small spherules (Fig. 2c). The spherules increase in size towards the equigranular dike center where they stand out against the more melanocratic cement. Spherulitic textures in some other dikes are restricted to 
individual intricately-shaped schlieren (Fig. 2d). The spherulitic sites have rims that appear reddish against the background of the massive rock. Within the schlieren, there are randomly-distributed spherules of different sizes with radiating feldspar cores and ironoxide rims. Outside the iron oxide rings, the spherules are commonly surrounded by leucocratic zone. Phlogopite phenocrysts occur both inside the spherules and in the interstitials between them. Some interstitials patches comprise quartz-carbonate material with abundant ore minerals (Fig. 2d-f).
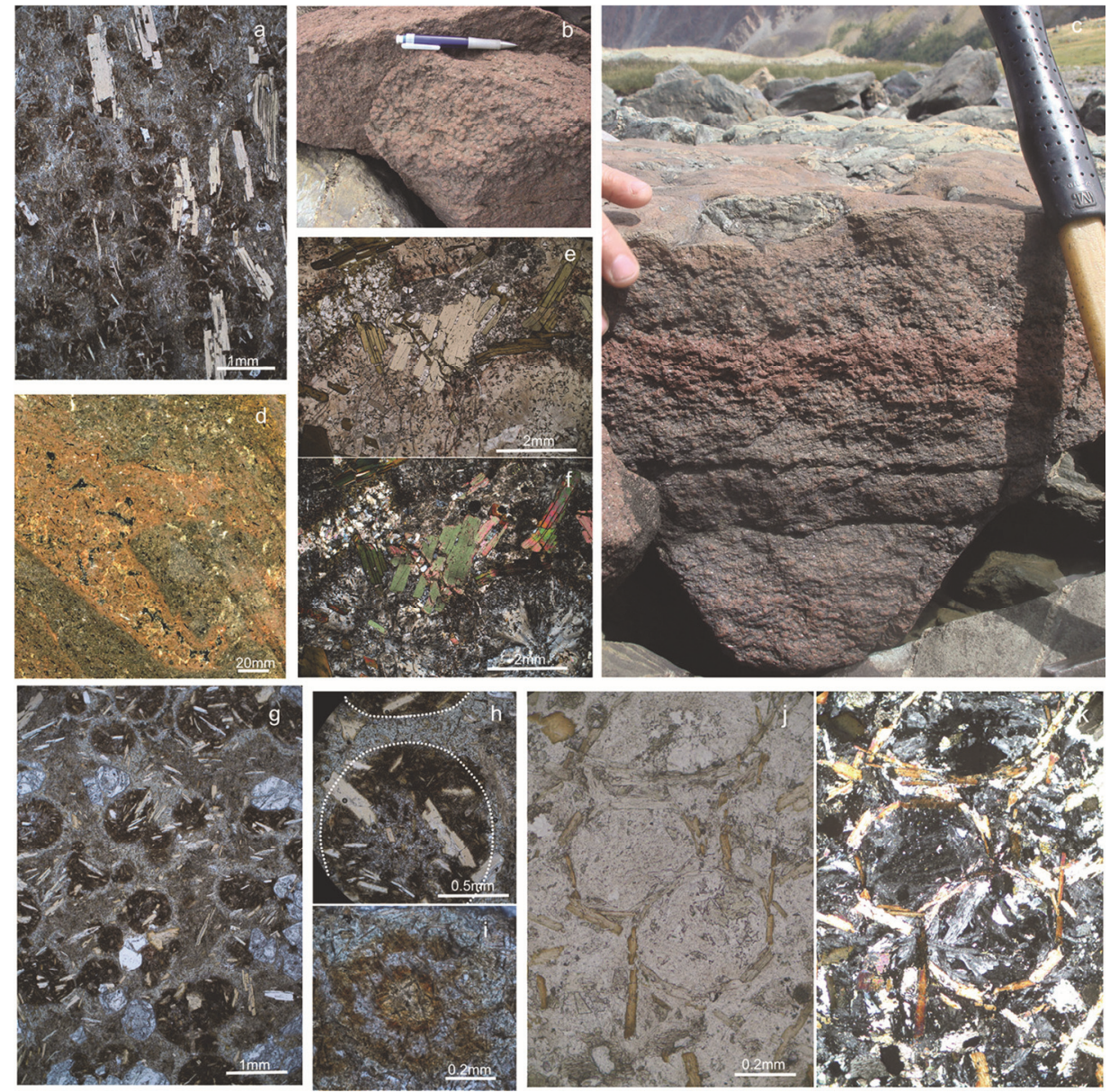

Fig. 2. Textures of lamprophyres: a - directional texture formed with biotite flakes; b - spherulitic texture on the weathered rock surface; $\mathrm{c}$ - crosscut of the dike with spherulitic texture; $\mathrm{d}$ - spherulitic schlieren formed with Kfsp-spherules, surrounded by quartz-carbonate cement with abundant ore minerals; e, f - thin section of the rock with spherules; $g$ - dark concentric mottles of iron oxide (color is independent of mineral boundaries); $\mathrm{h}$ - ocellar texture formed with phlogopite laths; i- secondary texture of the rocks - perhaps this is the Liesegang rings, formed by hydrothermal solutions; $\mathrm{j}, \mathrm{k}-$ microphotography of Yustyd lamprophyres - tangential laths of phlogopite form the ocellar texture of the rock. 
Some of the South Chuya dikes have spotted textures that show up as dark concentric spots of iron oxides. It is evident in Figure 2g-i that the color is independent of mineral boundaries; a phlogopite phenocryst crosses the mottled boundary without any visible change in color or shape.

Several of the Yustyd dikes show ocellar textures visible in thin sections only (Fig. $2 \mathrm{j}, \mathrm{k}$ ). The textural pattern is produced by phlogopite laths that encircle the ocelli. The latter are filled with calcite and K-Na feldspar in different proportions.

All dikes have a leucocratic or mesocratic matrix, typical for the lamprophyres, which encloses euhedral phenocrysts. The latter are, in some cases, pyroxenes or pseudomorphs after primary phenocrysts (olivine?), but typically phlogopite. The groundmass may be either vitreous or crystalline, with spehrulitic, poikilophytic, or idiomorphic textures.

The Tarkhata syenites have hypidiomorphic textures. There are schlieren of darkcolored minerals most often coexisting with apatite and titanite. Porphyritic segregations are of perthitic feldspar and plagioclase.

\subsection{Mineralogy of Chuya lamprophyres and Tarkhata syenites}

The mineralogy of the lamprophyres consists of rock-forming K-Na feldspar, phlogopite and pyroxene, and much less abundant plagioclase, quartz and others. The accessories are apatite and a few grains of zircon and titanite. The mineral assemblages of the Tarakhta rocks commonly include feldspar, plagioclase, biotite and quartz. Melanocratic varieties (monzodiorite and syenite) also contain varying percentages of amphibole, clinopyroxene, and orthopyroxene.

Rock-forming phlogopite in the lamprophyres occurs as subhedral phenocrysts and as groundmass crystals. The Tarkhata syenite likewise contains phlogopite $(>10 \%)$, though never as euhedral crystals.

The mica compositions on the Mg-Fe-Al diagram (Fig. 3, Table 1) fall in the phlogopite-eastonite field, i.e. they have high $\mathrm{Mg}$ and $\mathrm{Al}$ contents. Phlogopite phenocrysts in the lamprophyres range in size from a few millimeters to a few centimeters. Those in the lamprophyres commonly show bending and cracks along cleavage. Cracks are filled with quartz, calcite or occasionally with fluorite (Fig. 4a, b). In some instances, phlogopite makes up rather large aggregates consisting of strongly bent crystals of mica in quartzcarbonate cement (Fig. 4a). Phlogopite commonly forms coatings aligned with margins of dikes and, also, surrounds ocelli in ocellar lamprophyre (see above, Fig. 3j, 4e).

Most phlogopite crystals have thin ferrous rims. There are also cased crystals (Fig. 4d) and crystals with inverse zoning (Fig. 4c). Phlogopite from the South Chuya lamprophyres displays the highest magnesian contents compared to phlogopites from Yustyd lamprophyres. Intermediate between these two groups are those from syenite.

The compositions of the pyroxenes on the classification diagram $\left(\mathrm{MgSiO}_{3}-\mathrm{FeSiO}_{3}\right.$ $\mathrm{CaSiO}_{3}$ ) plot in the field of diopside-augite (Fig. 5, Table 2). In Tarkhata syenites and some South-Chuya lamprophyres ortho- and clinopyroxenes were found. Perhaps orthopyroxene belongs to the early paragenesis with olivine, which subsequently was replaced by the carbonate. 


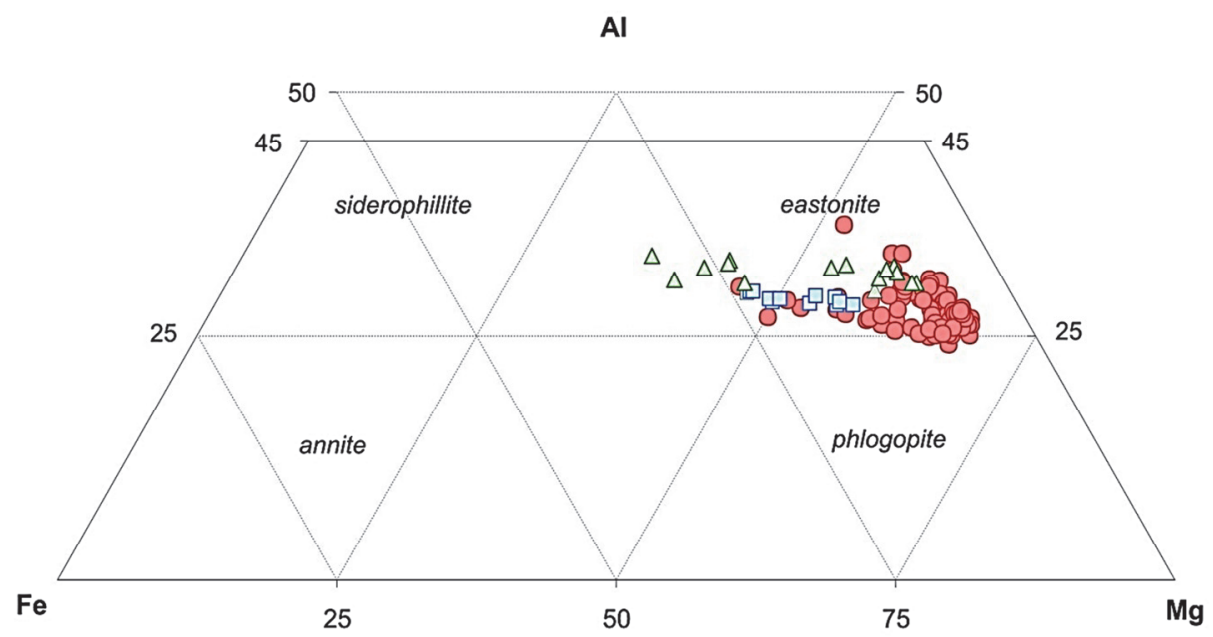

Fig. 3. Mica composition on Mg-Fe-Al diagram from lamprophyres and syenite. 1 - South-Chuya lamprophyres - red circles; 2 - Yustyd lamprophyres - green triangles; 3 - Tarkhata syenites - blue squares.

TABLE 1

Average contents and variances of chemical components for micas from lamprophyres and syenites (1 - South-Chuya lamprophyres; 2 - Tarkhata syenites; 3 - Yustyd lamprophyres) (n - number of analyses).

\begin{tabular}{|c|c|c|c|c|c|c|}
\hline \multirow{3}{*}{$\begin{array}{l}\text { Area } \\
\text { Rock }\end{array}$} & \multicolumn{4}{|c|}{ South Chuya area } & \multirow{2}{*}{\multicolumn{2}{|c|}{$\begin{array}{l}\text { Yustyd area } \\
\text { Lamprophyres }(\mathrm{n}=20)\end{array}$}} \\
\hline & \multicolumn{2}{|c|}{ Lamprophyres ( $\mathrm{n}=120$ ) } & \multicolumn{2}{|c|}{ Syenites $(\mathrm{n}=12)$} & & \\
\hline & av. & variance & av. & variance & av. & variance \\
\hline $\mathrm{SiO}_{2}$ & 40.66 & 8.77 & 38.91 & 0.75 & 39 & 9.36 \\
\hline $\mathrm{TiO}_{2}$ & 2.51 & 0.57 & 3.99 & 0.44 & 3.47 & 2.21 \\
\hline $\mathrm{Al}_{2} \mathrm{O}_{3}$ & 12.8 & 1.47 & 12.46 & 0.05 & 14.21 & 2.9 \\
\hline $\mathrm{MgO}$ & 22.9 & 8.42 & 17.75 & 1.65 & 17.42 & 16.99 \\
\hline $\mathrm{FeO}$ & 5.62 & 5.77 & 11.85 & 4.09 & 11.39 & 23.35 \\
\hline $\mathrm{CaO}$ & 0.06 & 0.01 & 0.02 & 0 & 0.06 & 0 \\
\hline $\mathrm{BaO}$ & 0.06 & 0 & no & no & 0.14 & 0.06 \\
\hline $\mathrm{MnO}$ & 0.03 & 0 & 0.14 & 0 & 0.1 & 0.02 \\
\hline $\mathrm{Cr}_{2} \mathrm{O}_{3}$ & 0.6 & 0.34 & 0.13 & 0.05 & 0.2 & 0.11 \\
\hline $\mathrm{K}_{2} \mathrm{O}$ & 9.78 & 0.23 & 9.69 & 0.02 & 8.88 & 0.89 \\
\hline $\mathrm{Na}_{2} \mathrm{O}$ & 0.15 & 0.01 & 0.16 & 0 & 0.64 & 1.5 \\
\hline $\mathrm{NiO}$ & 0.09 & 0.01 & no & no & 0.04 & 0 \\
\hline $\mathrm{F}$ & 1.61 & 0.2 & 1.75 & 0.06 & 1.32 & 0.12 \\
\hline $\mathrm{Cl}$ & 0.02 & 0 & 0.11 & 0 & 0.03 & 0 \\
\hline Total & 96.74 & 0.34 & 96.97 & 0.42 & 96.66 & 0.58 \\
\hline
\end{tabular}


TABLE 2

Average contents and variances of chemical compounds for pyroxenes (1 - South-Chuya lamprophyres; 2 - Yustyd lamprophyres; 3 - Tarkhata syenites) (n - number of analyses).

\begin{tabular}{|c|c|c|c|c|c|c|c|c|c|}
\hline Area & \multicolumn{7}{|c|}{ South Chuya area } & \multirow{2}{*}{\multicolumn{2}{|c|}{$\begin{array}{l}\text { Yustyd area } \\
\text { lamprophyres }\end{array}$}} \\
\hline Rock & lamprop & res & & syenites & & & & & \\
\hline \multirow[t]{2}{*}{ Mineral* } & \multicolumn{2}{|c|}{$\mathrm{Cpx}(\mathrm{n}=17)$} & \multirow[t]{2}{*}{ Opx } & \multicolumn{2}{|l|}{$\mathrm{Cpx}(\mathrm{n}=5)$} & \multicolumn{2}{|c|}{ Opx $(n=4)$} & \multicolumn{2}{|c|}{$\mathrm{Cpx}(\mathrm{n}=8)$} \\
\hline & av. & variance & & av. & variance & av. & variance & av. & variance \\
\hline $\mathrm{SiO}_{2}$ & 53.7 & 1.22 & 54.14 & 52.13 & 0.03 & 53.98 & 0.2 & 52.6 & 0.9 \\
\hline $\mathrm{TiO}_{2}$ & 0.46 & 0.03 & 0.41 & 0.52 & 0 & 0.21 & 0 & 0.58 & 0.02 \\
\hline $\mathrm{Al}_{2} \mathrm{O}_{3}$ & 1.29 & 0.65 & 1.05 & 1.48 & 0.1 & 0.61 & 0.01 & 2.25 & 0.31 \\
\hline $\mathrm{MgO}$ & 16.94 & 0.36 & 24.91 & 16.37 & 0.01 & 27.14 & 0.98 & 16 & 1.23 \\
\hline $\mathrm{FeO}$ & 5.07 & 1.04 & 18.14 & 7.29 & 0.62 & 16.03 & 1.5 & 5.21 & 1.34 \\
\hline $\mathrm{CaO}$ & 22.18 & 1.09 & 1.31 & 20.62 & 0.85 & 1.11 & 0.04 & 22.56 & 0.14 \\
\hline $\mathrm{MnO}$ & 0.16 & 0 & 0.48 & 0.28 & 0 & 0.39 & 0.01 & 0.13 & 0 \\
\hline $\mathrm{K}_{2} \mathrm{O}$ & 0.01 & 0 & 0.01 & 0.02 & 0 & 0 & 0 & 0.01 & 0 \\
\hline $\mathrm{Na}_{2} \mathrm{O}$ & 0.33 & 0.01 & 0.06 & 0.5 & 0.01 & 0.08 & 0 & 0.35 & 0 \\
\hline $\mathrm{Cr}_{2} \mathrm{O}_{3}$ & 0.15 & 0.02 & 0.03 & 0.13 & 0 & 0.25 & 0.04 & 0.42 & 0.1 \\
\hline Total & 100.29 & 0.16 & 100.52 & 99.34 & 0.01 & 99.79 & 0.03 & 100.14 & 0.52 \\
\hline
\end{tabular}

* - In the parentheses is the number of analyses.

TABLE 3

Average contents and variances of chemical compounds for feldspars in lamprophyres from different areas - South Chuya and Yustyd ( $\mathrm{n}$ - number of analyses).

\begin{tabular}{|c|c|c|c|c|c|c|}
\hline & \multirow{2}{*}{\multicolumn{2}{|c|}{$\begin{array}{l}\text { South Chuya lamprophyres } \\
\text { Kfsp }(n=15)\end{array}$}} & \multicolumn{4}{|c|}{ Yustyd lamprophyres } \\
\hline & & & \multicolumn{2}{|c|}{ Kfsp (n=9) } & \multicolumn{2}{|c|}{$\mathrm{Ab}(\mathrm{n}=16)$} \\
\hline & av. & variance & av. & variance & av. & variance \\
\hline $\mathrm{SiO}_{2}$ & 64.79 & 0.29 & 64.93 & 1.27 & 68.16 & 0.13 \\
\hline $\mathrm{Al}_{2} \mathrm{O}_{3}$ & 18.52 & 0.1 & 19.24 & 0.22 & 19.73 & 0.15 \\
\hline $\mathrm{FeO}$ & 0.35 & 0.04 & 0.37 & 0.04 & 0.2 & 0.02 \\
\hline $\mathrm{CaO}$ & 0.08 & 0.03 & 0.32 & 0.02 & 0.22 & 0.02 \\
\hline $\mathrm{K}_{2} \mathrm{O}$ & 15.17 & 2.3 & 11.6 & 8.54 & 0.44 & 0.29 \\
\hline $\mathrm{Na}_{2} \mathrm{O}$ & 1.13 & 0.78 & 3.27 & 5.55 & 10.91 & 0.15 \\
\hline Total & 100.1 & 0.44 & 99.86 & 0.31 & 99.8 & 0.24 \\
\hline
\end{tabular}




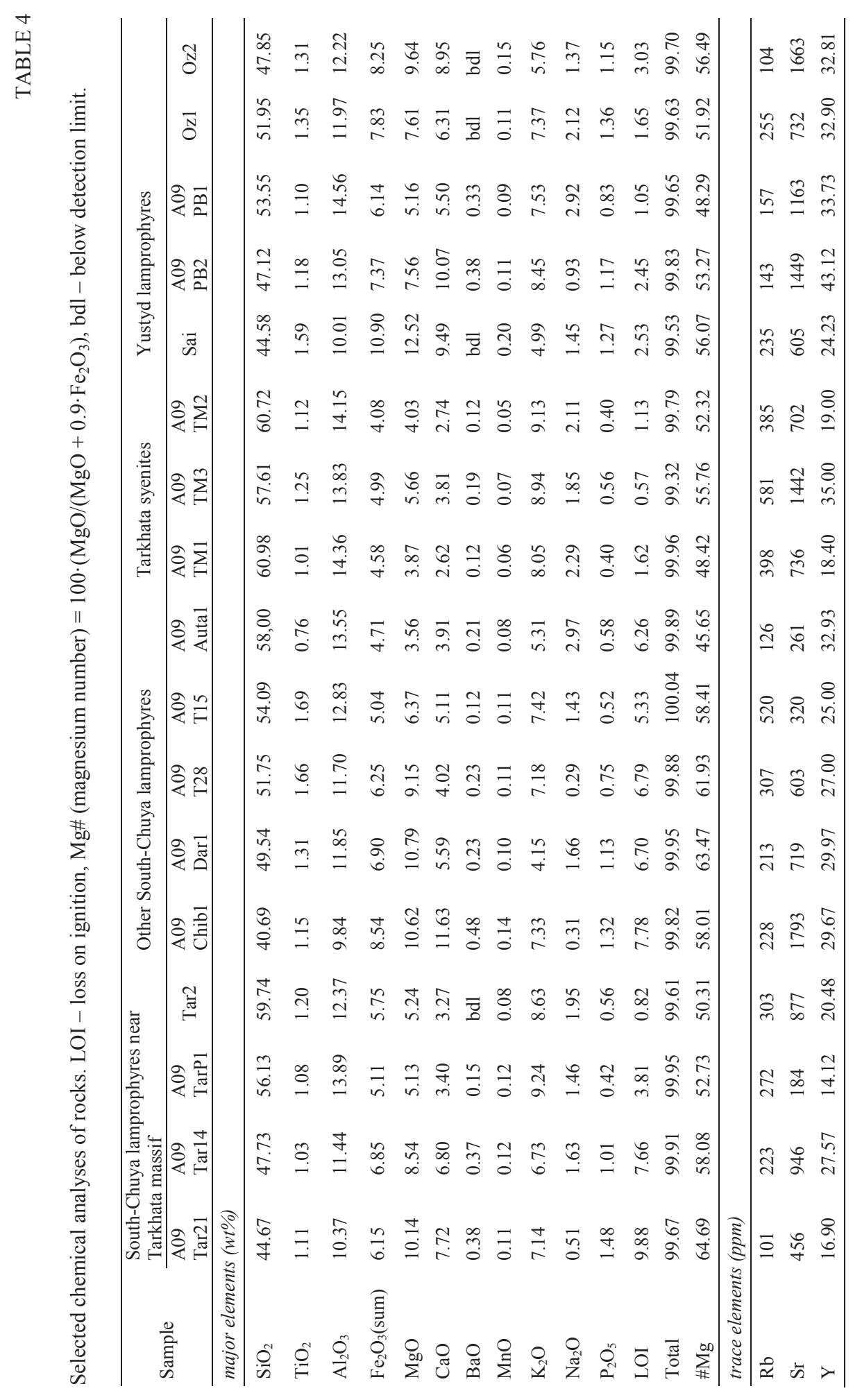




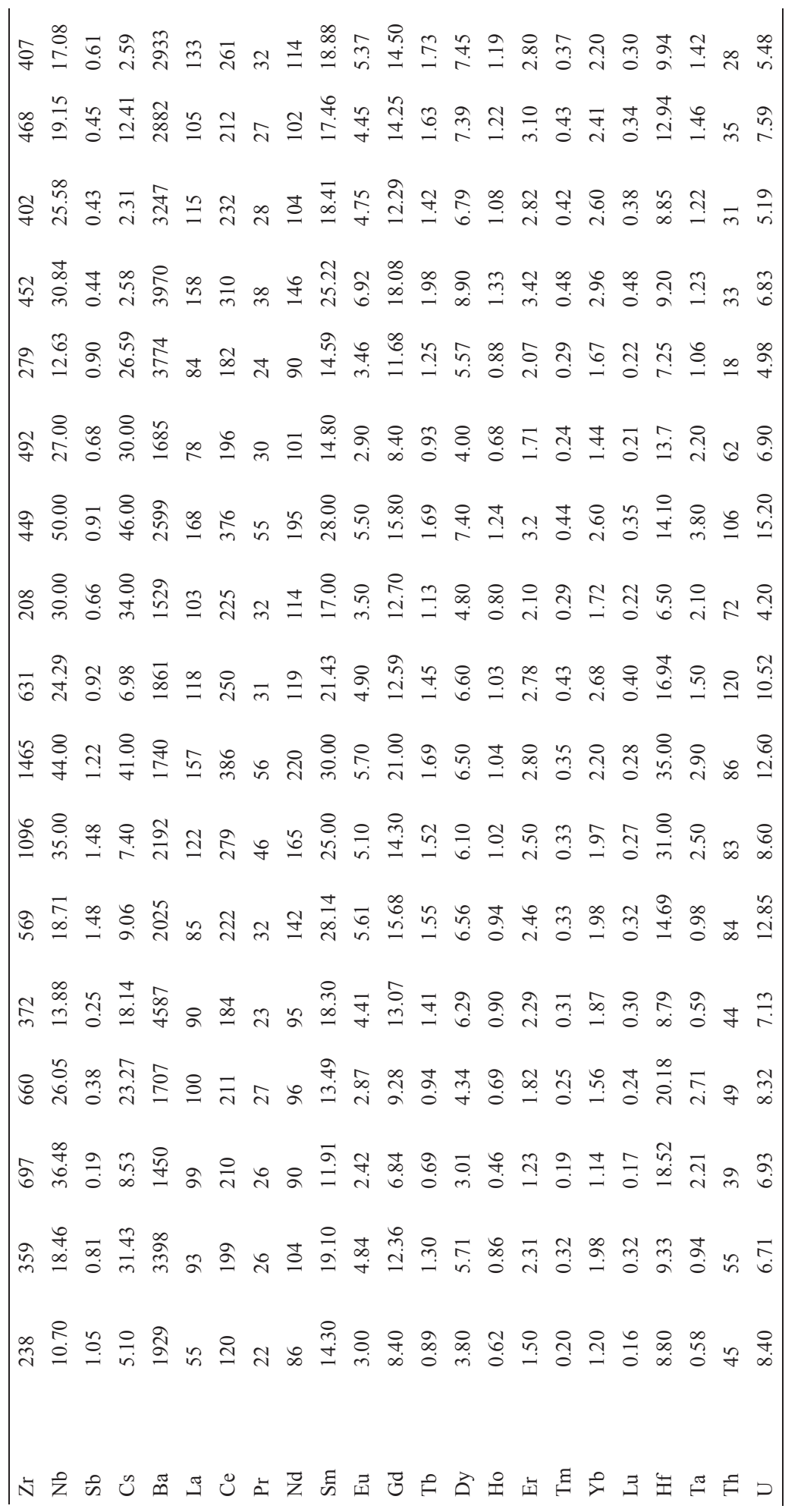



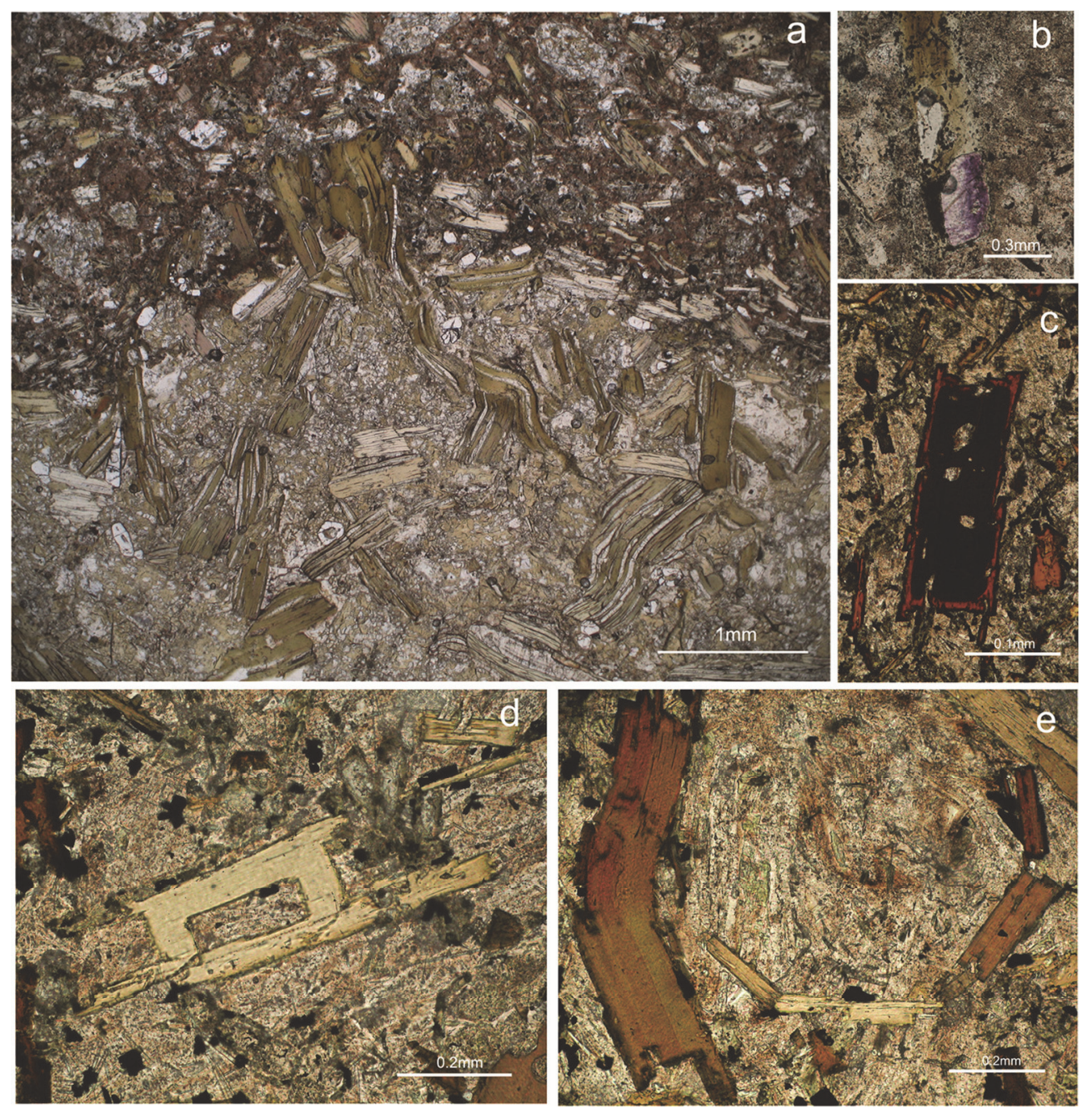

Fig. 4. Forms of mica in lamprophyres (see text for details).

Feldspar, a major groundmass constituent in the lamprophyres, occurs as subhedral or fine crystals. The feldspar spherulites in some of the Yustyd lamprophyres form a specific globular texture (Fig. 2e, f). Isomorphic substitution of $\mathrm{Fe}^{3+}$ for $\mathrm{Al}^{3+}$ caused the characteristic pink color of most Soth-Chuya lamprophyres. Perthitic structure is a characteristic feature that is evident from the composition corresponding to $\mathrm{Ab}$ in Figure 6 (Table 3). In some leucocratic parches, feldspar makes micropegmatitic aggregates with quartz (Fig. 7). 


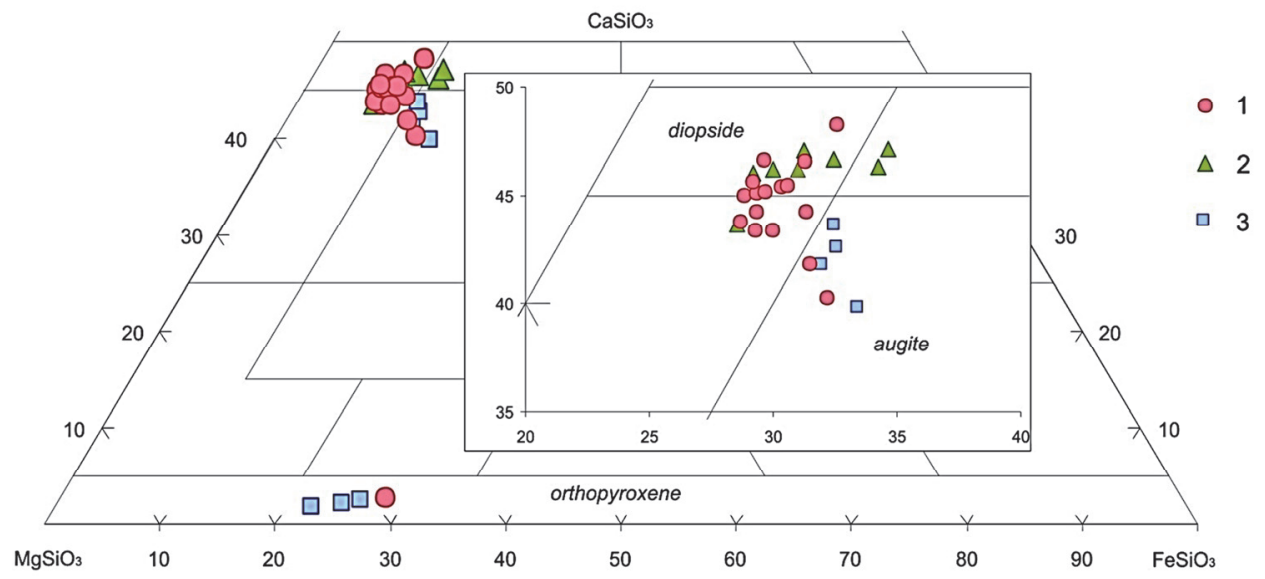

Fig. 5. $\mathrm{MgSiO}_{3}-\mathrm{FeSiO}_{3}-\mathrm{CaSiO}_{3}$ classification diagram for pyroxenes from lamprophyres and syenites. 1 - lamprophyres of the South-Chuya area; 2 - lamprophyres of the Yustyd area, 3 - syenites of the Tarkhata massif.

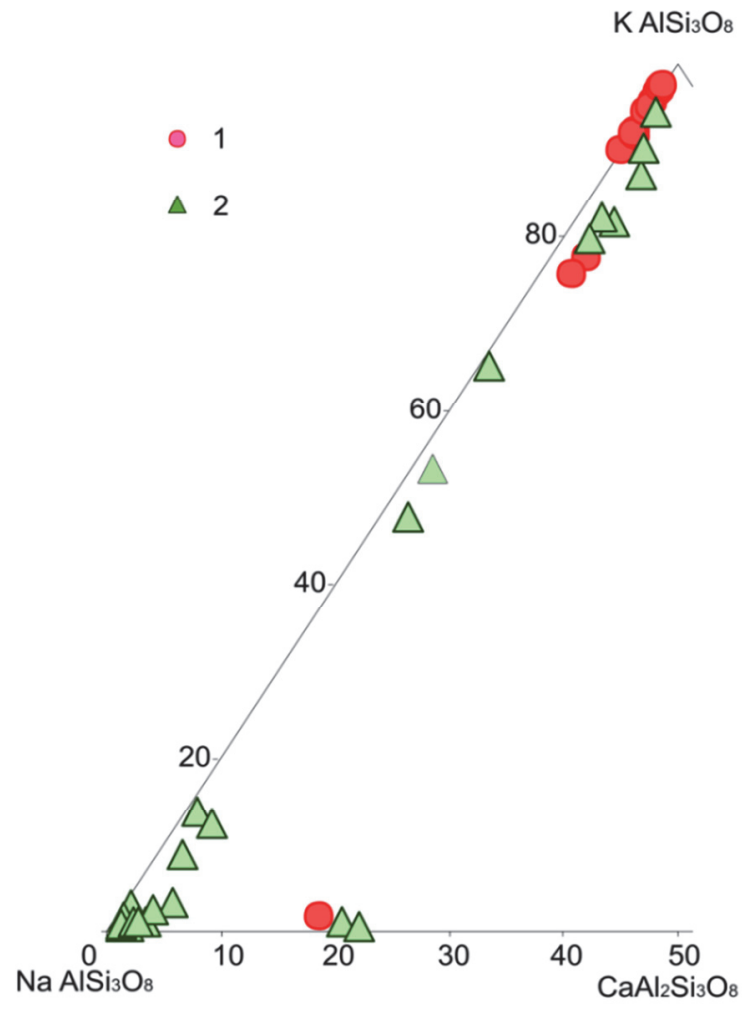

Fig. 6. Compositions of feldspar minerals from lamprophyres on the An-Ab-Ort termary diagram. 1 lamprophyres of the South-Chuya area; 2 - lamprophyres of the Yustyd area. 


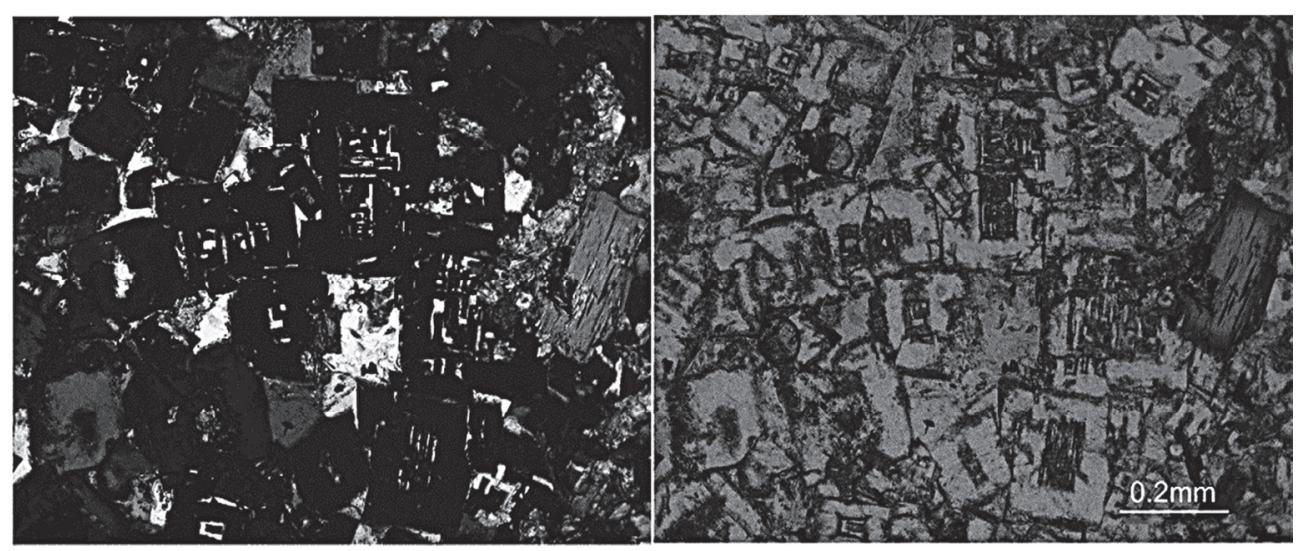

Fig. 7. Micropegmatitic aggregates in lamprophyres.

\section{Whole-rock chemistry}

Whole-rock chemical compositions of the lamprophyre- and syenite samples are compared in Fig. 8 (Table 1). In the total alkali - silica (TAS) diagram, lamprophyres split into two trends. One trend is alkaline (consisting of rocks from Yustyd area and some South-Chuya rocks, located near Tarkhata massive) and the other trend, with the remaining lamprophyres from the South-Chuya area, starts in the trachybasalt field and straddles the boundary between alkaline and subalkaline rocks. The two trends meet in the field of trachytes and joining with the Tarkhata samples.

Whole-rock $\mathrm{SiO}_{2}$ contents in the lamprophyres vary from $35-60 \mathrm{wt} \%$, the highest being in syenite $(57-60 \mathrm{wt} \%)$. Most of major oxides show linear correlations with $\mathrm{SiO}_{2} ; \mathrm{CaO}$, $\mathrm{MgO}, \mathrm{Fe}_{2} \mathrm{O}_{3}, \mathrm{MnO}$, and $\mathrm{P}_{2} \mathrm{O}_{5}$ decrease and $\mathrm{Al}_{2} \mathrm{O}_{3}$ increases with increasing $\mathrm{SiO}_{2}$. Correlation of silica with $\mathrm{K}_{2} \mathrm{O}$ and $\mathrm{Na}_{2} \mathrm{O}$ is not so marked because of the high mobility of the alkalis. The content of $\mathrm{TiO}_{2}$ is high $(1-2 \mathrm{wt} \%)$ and similar for all rocks. The loss on ignition LOI vs. $\mathrm{Mg} \#\left(\mathrm{Mg} \#=\mathrm{MgO} \cdot 100 /\left(\mathrm{Fe}_{2} \mathrm{O}_{3} \cdot 0.9+\mathrm{MgO}\right)\right)$ diagram shows that both LOI and $\mathrm{Mg} \#$ are high, with nearly all samples falling in the ranges $\sim 40-60 \%$ and $1-18 \%$, respectively (Fig. 8).

Thus, according to the diagrams (Fig. 8), the lamprophyres vary from mafic to intermediate, from alkaline to subalkaline, and are rich in magnesium, titanium, potassium and volatiles. Lamprophyres from the two localities have similar compositions, except on the $\mathrm{Al}_{2} \mathrm{O}_{3}-\mathrm{Fe}_{2} \mathrm{O}_{3}$ diagram. Syenites are alkali-rich and all have their trends overlapping those of the lamprophyres. Five specimens of lamprophyre show petrographic and chemical evidence of strong hydrothermal alteration, including high LOI and $\mathrm{Na}_{2} \mathrm{O}$ and very low $\mathrm{K}_{2} \mathrm{O}$.

The trace-element chemistry of the lamprophyres and syenites (Table 4) is illustrated on PM-normalized multi-element- and REE spider diagrams (Fig. 9). The patterns and the element abundances are similar in shape and absolute concentrations for lamprophyres from both areas and for syenites. Negative anomalies in HFSE- (Nb, Ta, Hf, Zr, Ti) and $\mathrm{Sr}$ also coincide. The main difference between the Yustyd- and South-Chuya lamrophyres and the 
Tarkhata syenites is in the magnitude of anomalies: the strongest anomalies appear in dike rocks from the South-Chuya area.
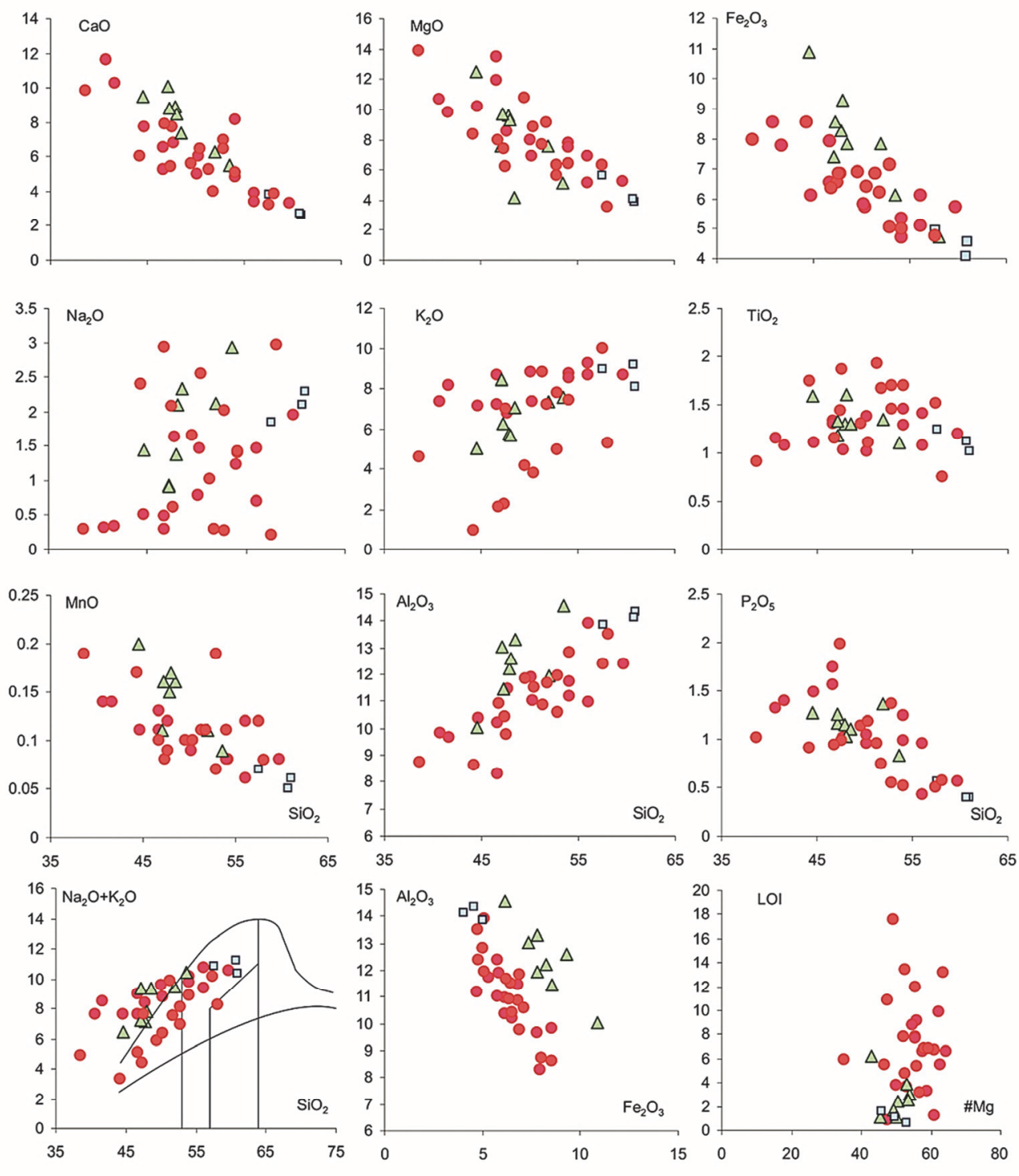

$1 \bullet 2 \Delta 3$ 口

Fig. 8. Petrochemical diagrams for lamprophyres and syenites. Symbols as in figure 3. 

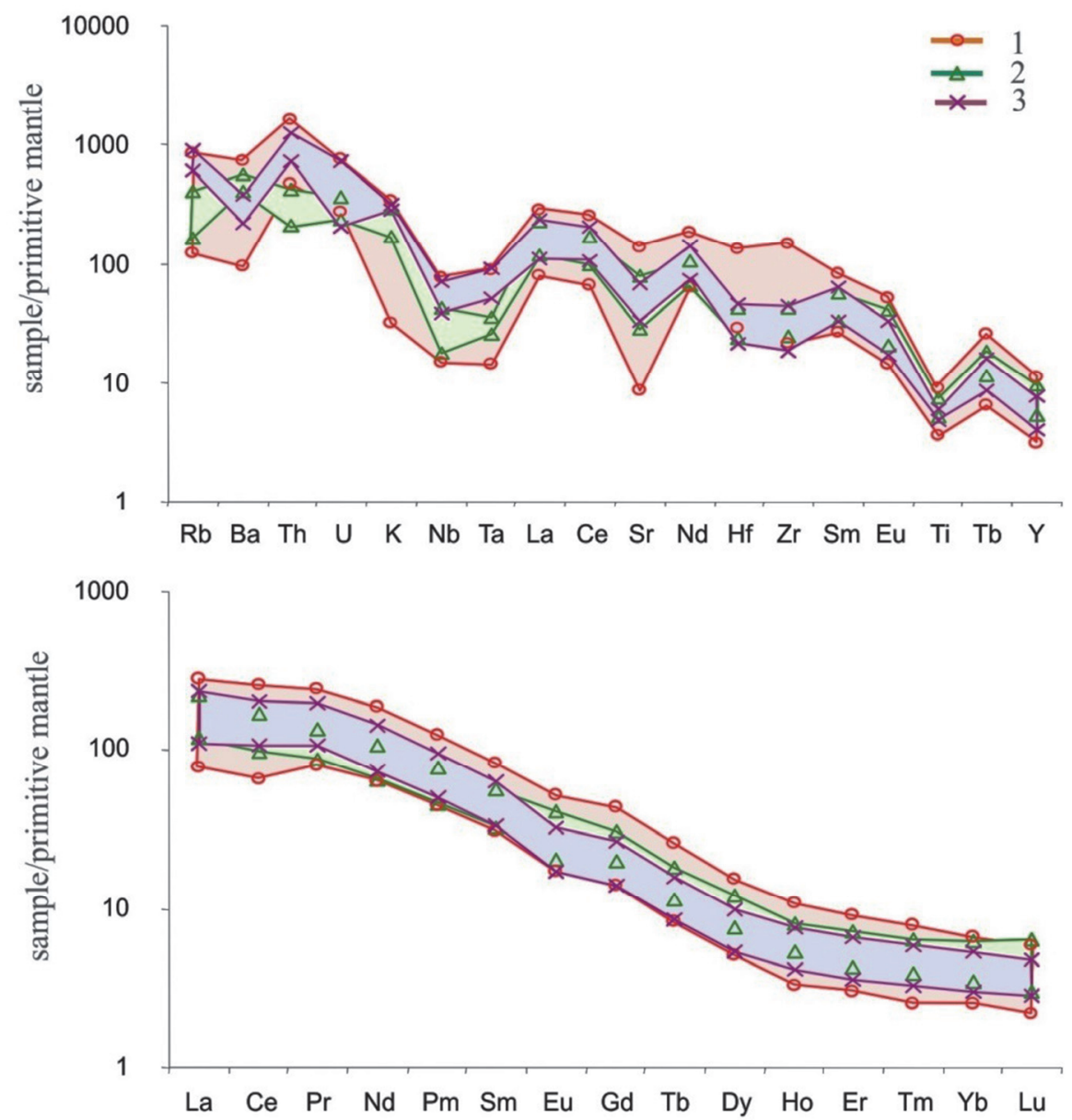

Fig. 9. Spider-diagram and REE PM-normalized diagram for lamprophyres and Tarkhata syenites (normalization after McDonough et al. 1992). 1 - lamprophyres of the South-Chuya area; 2 lamprophyres of the Yustyd area, 3 - syenites of the Tarkhata massif.

The REE pattern shows LREE enrichment and HREE depletion, which is typical of low-degree partial melting of garnet containing mantle source. The absence of a negative Eu anomaly suggests the lack of feldspar fraction in the melt.

\section{Discussion}

\subsection{Textures}

The initial lamprophyre melt was obviously saturated with water and other fluids, as one can infer from the presence of phlogopite as a rock-forming phase, from the volcanicpipe appearance of some dikes, and from widespread auto-metasomatism (abundant matrix carbonate and carbonate pseudomorphs). Furthermore, alteration along the dike margins 
(phlogopite coatings) may be due to water contents being higher in the lamprophyre melt than in the country rock. At the boundary of sharp change in chemical potential, there appear to have been conditions conducive to large-scale crystallization of hydrous minerals, i.e. mica, with its crystals aligning with the fast-flowing low-viscosity melt. Along with the composition of phlogopite containing rather large amounts of $\mathrm{F}$ and $\mathrm{Cl}$, these features are evidence of a fluid with a carbonate-chloride-fluorine chemistry.

Evolution of the lamprophyre melt commonly includes a stage in which the cooling melt segregates into two immiscible liquids (Panina, Motorina 2008; Safonov 2007). This is, possibly, the cause of the distinctive lamprophyre textures. Spherulitic textures can appear at late stages of dike crystallization, as it is especially evident in the intricate forms of schlieren. The latest batches of gradually cooling magma contain much more fluid than the earliest ones. During cooling, this provokes melt segregation into a silicate component and predominantly carbonate component. Rapid crystallization of the silicate component produces K-Na-feldspar spherules. The remaining liquid interacts with the spherules which thereby acquire albite-hematitic rims and also crystallizes as quartz-carbonate patches in the interstitial space. In the ocellar dikes, the carbonate ocelli may have crystallized as drops of carbonate melt released during cooling and segregation of the carbonate-silicate melt. However, late hydrothermal alteration may play some minor role as well. The feldsparcarbonate-bearing ocelli may be leucite pseudomorphs on the basis of their rounded form and KFsp-calcite composition. On the other hand, nepheline or kalsilite is not detected. Another hypothesis of the ocelli origin is the liquid immiscibility of predominantly carbonate drops in the silicate melt. The annular patterns looking like Liesegang rings in some dikes may result from uneven diffusion of solutions in microporous-, colloidal-, or gel materials. The microporosity of lamprophyres may be easily explainable as due to high contents of volatiles in the parent melt and by the rapid crystallization of the dikes.

\subsection{Micas}

The composition of the ferrous-magnesian mica has petrological implications (Bushlyakov 1969; Nebera 2007; Phershtater, Borodina 1975; Righter, Carmichael 1996); it is considered both a thermometer and barometer. For instance, titanium with its small meltmineral partitioning coefficient, accumulates in the melt and its content in phlogopite is in negative correlation with the crystallization temperature of the latter. Thus, the general trend is that phlogopites from the Yustyd lamprophyre, which are the lowest in $\mathrm{Mg}$ and relatively high in Ti, crystallized at lower temperatures than did those from the other rocks.

The diagram (Fig. 10) gives an idea of the phlogopite crystallization depth. The phlogopite samples from the Tarkhata complex plot at the lower boundary of subvolcanic rocks and some phlogopites from the dikes fall in the field of subvolcanic rocks. The phenocrysts thus crystallized at relatively shallow depths and some phlogopites crystallized in situ within the dike interiors. The subvolcanic origin of the rocks is consistent with the volcanic-pipe morphology of the dikes. 


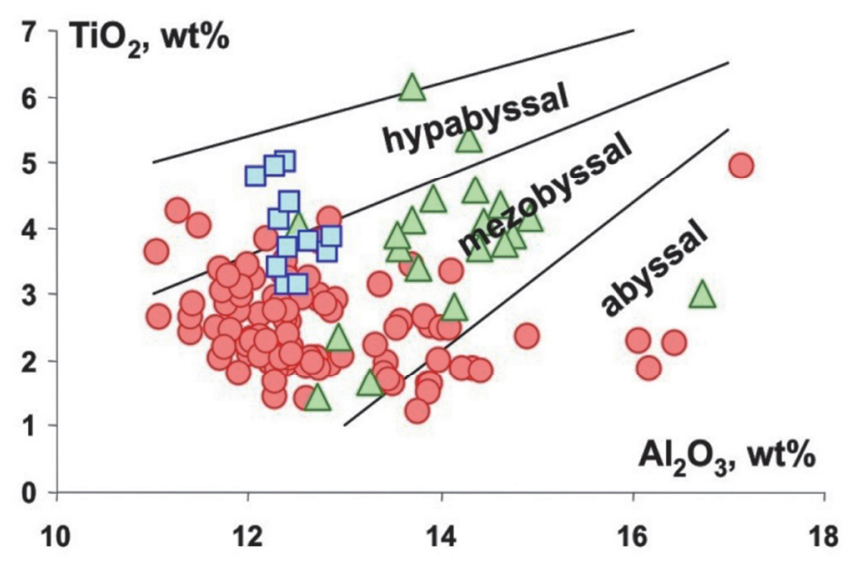

Fig. 10. $\mathrm{Al}_{2} \mathrm{O}_{3}-\mathrm{TiO}_{2}$ diagram for micas. Symbols as in figure 3 .

\subsection{Whole-rock chemistry}

Linear correlations of most major oxides with $\mathrm{SiO}_{2}$ in lamprophyres, and the two trends in the total alkali-silica (TAS) and $\mathrm{Al}_{2} \mathrm{O}_{3}-\mathrm{Fe}_{2} \mathrm{O}_{3}$ diagrams that meet in the field of trachyte and join the Tarkhata massive samples (Fig. 8, Table 4) may result from the cotectic crystallization of rock-forming silicates, oxides and phosphates. The TAS diagram illustrates the evolution of two melts with different proportions of components that complete their crystallization at the same eutectic point.

Rocks with the highest LOI are altered varieties. They were analyzed especially to identify the elements that may have been mobile during weathering. LOI turned out to be inversely correlated with $\mathrm{K}_{2} \mathrm{O}$, possibly as a consequence of strong postmagmatic hydrothermal alteration.

Position of points of the Tarkhata syenites at the end of the trends on the TAS and Harker diagrams indicates a higher degree of fractionation of the melt than for the lamprophyres. At the same time the Tarkhata plutonic rocks have provided one of the

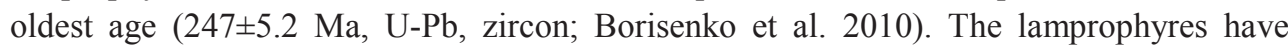
given slightly younger Ar-Ar ages(244-242 Ma, Ar-Ar age method) except for a SHRIMP $\mathrm{U}-\mathrm{Pb}$ date of $250 \mathrm{Ma}$. It is suggested that the older zircons might have been brought into the magma chamber from the alkaline mafic source. Most of samples were selected from the more acid and better exposed part of the Tarkhata massif, while early explorers were fixed basic rocks (e. g. monzogabbro). Most of samples were selected from the more acid and better exposed part of the Tarkhata massif, while early explorers (Izokh et al. 1987) studied basic rocks (e. g. monzogabbro). Thus high silica content in the investigated samples is the result of the intrachamber fractionation and the bulk composition of the melt forming Tarkhata intrusion was more basic. 


\section{Conclusion}

The coincident distribution pattern of rare and rare-earth elements, the similarity of mineral composition, petrochemical and geochemical characteristics in both space and time overlapping indicates the formation of Chuya lamprophyres and Tarkhata rocks from the geochemically similar magma sources or their cogenetic.

The independent trends in the $\mathrm{Al}_{2} \mathrm{O}_{3}-\mathrm{Fe}_{2} \mathrm{O}_{3}$, and the systematic differences in mineral chemistry of lamprophyres of the South Chuya- and Yustyd dike areas and the Tarkhata pluton, indicate some significant differences between their crystallization. It could be related to different $P T$ conditions of crystallization for the dike and massif rocks (South Chuya lamprophyres and Tarkhata syenites) and different host rocks for the rocks of different areas.

Acknowledgements. I am grateful to dr. Marek Awdankiewicz for organizing the conference, which resulted in this article and my PhD work. I wish to express special thanks to Evgenii Dashkiewicz for his helpful assistance in the field. Many thanks are due to dr. Andrey Izokh and dr. Galina Pavlova for their remarks and help in the interpretation of the data. Helpful comments of this paper by two anonymous reviewers are greatly appreciated.

\section{References}

Borisenko, A.S., Pavlova, G.G., Vasyukova, E.A., Travin, A.V., Goverdovskii, V.A., \& Gusev, N.I. (2010). Ages of lamprophyres of Altai and NE Mongolia and their relations with other types of magmatism and ore mineralization. In: A.I. Chernyh \& R.S. Rodina (Eds.), Geology and ore deposits of Siberia. pp. 143-148. Novosibirsk: SNIIGGiMS.

Bushlyakov, I.N. (1969). Titanium content in the amphibole and biotite from granitoids as an indicator of the conditions of their formation. Reports of AS USSR 186(4), 1154-1157.

Dobretsov, N.L., Borisenko, A.S., Isokh, A.E., \& Zhmodik, S.M. (2010). A thermochemical model of Eurasian Permo-Triassic mantle plumes as basis for prediction and exploration for $\mathrm{Cu}-\mathrm{Ni}$-PGE and rare-metal ore deposites. Russian Geology and Geophysics, 51(9), 1159-1187.

Izokh, E.P., Kononov, A.N., \& Kononov, O.A. (1987). Systematic and formational analysis of the granitoids of the Gorny Altai. Systematic of the magmatic formations. Novosibirsk: Nauka. 97-147.

McDonough, W.F., Sun, S., \& Ringwood, E.A. (1992). K, Rb and Cs in the earth and moon and the evolution of the earth's mantle. Geochimica Cosmochimica Acta, 56, 1001-1012.

Nebera, T.S. (2007). Petrogenetic significance of biotite from granitoids of the Novosibirsk Ob. In: Petrology of magmatic and metamorphic complexes, Tomsk. 6, 113-118. Tomsk State University.

Obolenskaya, R.V. (1971) Chuya complex of alkali basaltoids of Gorny Altai. Novosbirsk: Nauka.

Panina, L.I., \& Motorina, I.V. (2008). Liquid immiscibility of abyssal magmas and origin of carbonatite melt. Geochemistry, 5, 487-504.

Phershtater, G.B., \& Borodina, N.S. (1975) Petrology of magmatic granitoids (on the sample of Ural). Moscow: Nauka.

Righter, K., \& Carmichael, I.S.E. (1996). Phase equilibria of phlogopite lamprophyres from western Mexico: biotite-liquid equilibria and $P$ - $T$ estimates for biotite-bearing igneous rocks. Contributions to Mineralogy and Petrology 123, 1-21.

Safonov, O.G. (2007) Evolution models of abyssal alkali liquids. Thesis of doctoral dissertation. Moscow. 